SSOP, Washington, DC 20402-0328, 202-512-1800. Request stock number 065-000-00871-8. The report also is accessible via the Internet at gopher.ed. gov: 10000 or http://www. ed.gov/NCES/. A summary of this study is in the September 16, 1996 issue of Higher Education and $\mathrm{Na}$ tional Affairs, American Council on Education, One Dupont Circle, N.W., Washington, DC 20036.

Reprinted with permission of the Commission on Professionals in Science and Technology.

\section{Graduate Assistants Pitch in at APSA}

Four graduate students in political science are contributing to the daily operations of an association to which, in a few years, they will contribute their intellectual gifts. Graduate assistants Crystal Roach and Patti Shea, first-year graduate students in American University's public policy program, worked to generate the 1996-98 Directory of Members, processed Annual Meeting panel paper proposals under the new central processing system, and continue to work on the 1997 Annual Meeting. Jon Nakagawa, firstyear student in the political science department at George Washington University, also helped generate the Directory and works in Membership along with Sean Dugan, a first-year student at Georgetown University's School of Foreign Service.

In addition to graduate assistants, APSA employs several undergraduate interns each year through the work-study program at Georgetown University and a special relationship with Mount Vernon College at George Washington University. Interns help maintain the APSA website, assist in the publications and membership offices, and aid in several aspects of planning the Annual Meeting.

\section{Women's Caucus-South Elects New Officers}

The Women's Caucus for Political Science-South recently announced the election of officers for the 1997 term. They include Laura van Assen- delft, Mary Baldwin College, President; Wendy Gunther-Canada, University of Alabama, Vice-President and Newsletter Editor; Susan Roberts, Davidson College, Secretary; and Laura Woliver, University of South Carolina, Treasurer.

\section{Pi Sigma Alpha News}

\section{Distinguished Speaker Videotape} Series. Pi Sigma Alpha has begun publication of a series of videotaped lectures by eminent political scientists as a way for students to get first-hand exposure to some of the leading thinkers in the discipline. The first tape in the series is a talk delivered by Robert A. Dahl at the 1996 APSA Annual Meeting and titled "Equality and Inequality: Facts and Causes in a Normative Perspective." The videotapes are available to Pi Sigma Alpha chapters which can then organize meetings, discussion groups or debates around screenings. Contact the Pi Sigma Alpha National Office for details.

Internet Access. Pi Sigma Alpha's World Wide Web Site (http://www.georgetown.edu/departments/gov-
Albany State College

Brigham Young University

East Central Univ. (Oklahoma)

Eastern Washington University

Univ. of Florida

Univ. Of Guam

Hartwick College

Univ. Of Illinois-Springfield

Univ. Of Illinois-Urbana

Illinois State Univ.

Marquette Univ.

Mary Washington College

Univ. of Maryland-Baltimore Co.

Univ. Of Massachusetts

Univ. Of Michigan

Mississippi Valley State Univ.

Univ. Of Montana

Univ. Of Nebraska

New Mexico State Univ.

Northeastern Univ.

Univ. Of Notre Dame

Purdue Univ.-Calumet

Coll. Of St. Francis (Joliet, IL)

St. Francis Coll. (Loretto, PA) Model U.N. for high school students

St. Olaf College

San Jose State Univ.

Utah State Univ.

Wake Forest Univ.

Washington \& Lee Univ.

Winthrop Univ.

The members of the Grants Committee were James I. Lengle (Georgetown University and $\Pi \Sigma$ A Executive Director), Karl A Cerny (Georgetown), and Maurice Woodard (Howard University).

For more information on Pi Sigma Alpha, please contact Nancy McManus at (202) 483-2512 or E-mail at pisigmaa@guvax.georgetown.edu.
Public issues forums

Regional student research conference

Initiation banquet

Political science career luncheons

Essay contest and awards

Acquisition of political science library materials

Political Science Department pamphlet publication

Essay contest

Seminar series for women's shelter residents

Regional student political science conference

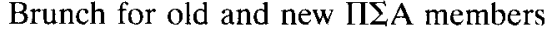

Scholarship competition for high school seniors

National political speaker and reception

Awards banquet

Survey of alumni members and chapter history project

Visiting scholar lecture; debate on First Amendment topic

Banquet with speech by Montana governor Racicot Paper competition and awards banquet

Symposium on US-Mexico relations

Speaker; awards for best papers in public law and international relations

Essay contest for middle school students

Student attendance at Indiana Political Science Conference and banquet

Student attendance at MWPSA Conference

Best paper awards

Convocation and awards ceremony

Induction banquet and speaker

Guest speaker on narcotics trafficking in Latin America

Symposium on Elshtain's Democracy on Trial in conjunction with the author's visit to the university

Symposium on desegregation and busing 
ernment/psa) contains all the $\mathrm{Na}$ tional Office publications and administrative forms, as well as $P i$ Sigma Alpha Newsletter. Chapters with home pages should give their addresses to the National Office so that they can be listed there.

Chapter Activity Grants Awarded. $\Pi \Sigma A$ chapters in the following schools received Chapter Activity Grants for 1996-97:

\section{Additional Dissertation Listing}

The following dissertations should be included in the compilation of completed doctoral dissertations in political science, 1995, listed in the December 1996 issue of PS.

\section{American Government}

Clayton, Dewey: B.A., Morehouse College, 1981; M.P.A., North Carolina Central University, 1987; Ph.D., University of Missouri-Columbia, 1995. The Politics of Redistricting: A North Carolina Case Study. University of MissouriColumbia.

\section{Comparative Politics}

An, Soon Cheol: B.A., Dankook University (Korea), 1985; M.A., Oklahoma
State University, 1987; Ph.D., University of Missouri-Columbia, 1995. Electoral Choice in Korea: A Spatial Analysis of Ideology and Sophisticated Voting. University of Missouri-Columbia.

Birch, Timothy J: B.A., University of Manchester, 1985, M.A., University of Missouri-Columbia, 1989; Ph.D., Ibid., 1995. After the Threat: NATO and European Defense in the Post-Cold War Era. University of Missouri-Columbia.

DaSoller, Claudio: B.A., The Polytechnic of Central London (London), 1986; M.A., University of Missouri-Columbia, 1989; Ph.D., Ibid., 1995. The Nonprofit Sector in the Fields of International Relief, Health and Nutrition, and Food Aid: Private Voluntary Organizations and the State. University of MissouriColumbia.

Jawadi, Mostafa: Mohamed V. University (Morocco), 1976, License in Law; M.P.A., California State University, Chico, 1988; Ph.D., University of Missouri-Columbia, 1995. Regional Integration in the Maghreb. University of Missouri-Columbia.

Lee, Wonkyoo: B.A., Seoul National University (Korea), 1977; M.P.A., Ibid., 1981; Ph.D., University of Missouri-Columbia, 1995. Political Culture in the Republic of Korea and Its Effects on Parties and Elections. University of Missouri-Columbia.

Veney, Cassandra R.: B.A., Syracuse University, 1982; M.A., Howard Univer- sity, 1988; Ph.D., University of MissouriColumbia, 1995. The Politics of Refugee Relief Programs in Kenya. University of Missouri-Columbia.

\section{International Relations}

Chung, Sam-man: B.S. Republic of Korean Naval Academy, 1981; M.A., National Defense College (Korea), 1990; Ph.D., University of Missouri-Columbia, 1996. Causes and Effects of U.S. Military Expenditures (Time Series Models and Applications). University of MissouriColumbia.

Park, Chang-Kwoun: B.A., Korea Naval Academy, 1981; M.A., National Defense College (Korea), 1989; Ph.D. University of Missouri-Columbia, 1996. Political Consequences of Shows-ofForce. University of Missouri-Columbia.

Song, Seung-jong: B.A., Korea Military Academy, 1981; M.A., National Defense College (Korea), 1989; Ph.D., University of MBFR and CFE. University of Missouri-Columbia.

\section{Methodology}

MacDonald, John T.: B.S., University of Minnesota-Minneapolis, 1980; M.P.A., ibid, 1985; Ph.D., University of MissouriColumbia, 1995. Information Theory, Cellular Autonata, and Political Science. University of Missouri-Columbia. 